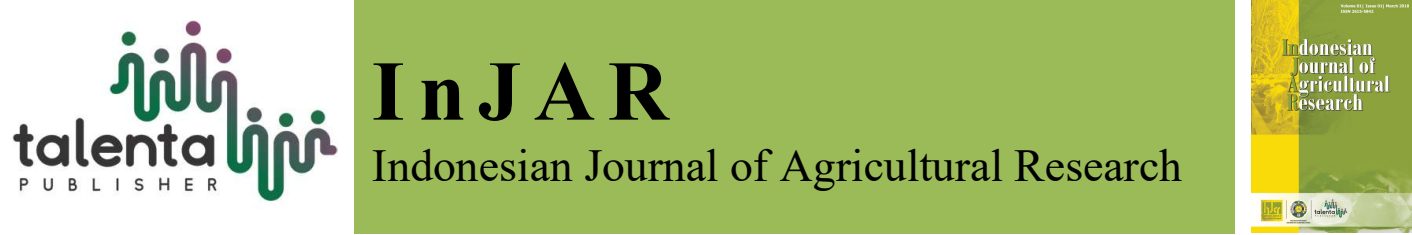

\title{
Growth and Yields Response of Some Varieties of Soybean (Glycine Max (L) Merill) on Ultisol Soil
}

\author{
Syariani Br. Tambunan ${ }^{*}$, Afkar ${ }^{2}$, and Nico Syahputra Sebayang ${ }^{1}$ \\ ${ }^{1}$ Agrotechnology, Gunung Leuser University, Aceh Tenggara, Indonesia \\ ${ }^{2}$ Biology, Gunung Leuser University, Aceh Tenggara, Indonesia
}

\begin{abstract}
Soybean is an agricultural product that has a good nutritional value, especially Protein content. This study aims to find superior varieties that have a wide adaptation to the sour soil especially in Ultisol soils. The study was conducted in Gulo Village, Darul Hasanah Sub-District, Southeast Aceh Regency, Aceh Province, from May to September 2019. The study used a non factorial randomized block design (RBD), with 4 treatment varieties (V) levels that were repeated as many as 4 replications; namely V1: Anjasmoro Varieties, V2: Dena Varieties, V3: Deja Varieties 1, V4: Detaptive Varieties 1, Variance analysis test results showed that the plant height was 1 WAP, Age $2 \mathrm{WAP}$, Age 3 WAP, Age 4 WAP, Age 5 WAP, and Age 6 WAP had no significant effect. However the highest yield on 1 WAP was found in variety V4 (10.40) in the second test and the lowest was in the first test. V2 was second test. While the best number of segments and branches were produced by V3 treatment. The best results for the total number of pods, number of pods, total empty pods, number of sample plant seeds and weight of sample plant seeds were produced by treatment V3.
\end{abstract}

Keywords: Southeast Aceh, soybean, ultisol, varieties

Received 30 September 2019 | Revised 14 February 2020 | Accepted 03 March 2020

\section{Introduction}

National soybean needs from year to year has increased. On the other hand soybean production has decreased. The decline in soybean production is the impact of reduced soybean harvest area. Based on the Ministry of Agriculture data, in 2017 soybean harvested area recorded only 446.000 ha, shrinking from 2016 which reached 576.000 ha and in 2015 amounting to 614.000 ha. With such minimal land area, the resulting production cannot be raised. Based on forecast figures, in 2017 soybean production was 675 thousand tons. That was smaller than 2016 and 2015 which reached 859 thousand tons and 963 thousand tons.Superior varieties are technological innovations that should be easily adopted by farmers and provide a significant contribution in increasing production. Superior varieties have characteristics such as high yields, early maturity, and resistant to biotic stress (pests and diseases) and abiotics (physical

\footnotetext{
*Corresponding author at: Agrotechnology, Gunung Leuser University, Kutacane Bambel, Kabupaten Aceh

Tenggara, Aceh, 24651, Indonesia

E-mail address: syariani979@gmail.com
}

Copyright (C) Indonesian Journal of Agricultural Research 2019 Published by Talenta Publisher p-ISSN: 2622-7681 | e-ISSN: 2615-5842 | DOI 10.32734/injar.v2i3.2035

Journal Homepage: https://talenta.usu.ac.id/InJAR 
environment). Superior varieties of soybeans that have been planted in Indonesia from 1918 to 2008 are Anjasmoro and Grobogan.

This variety is a superior variety of the Ministry of Agriculture which is being developed in many regions including Yogyakarta Special Region, Aceh Special Region, Pasuruan, Bojonegoro, Tuban, Jember, Malang, Kalimantan, Bali and Bima Regency. Anjasmoro varieties have large seed sizes (14.8-15.3 grams/100 seeds) and have high yield potential (2.3 tons / ha) and the seeds are also most preferred by tofu and tempe craftsmen for use as raw materials [1]. In general, the new superior varieties are expected to fulfill several criteria including increasing production, improving production stability, fulfilling quality standards according to cropping patterns applied by farmers and according to different consumer demands in each region.

Ultisol soil can be found in Sumatra, Kalimantan, Sulawesi and Irian Jaya [2], reaching $45,794,000$ ha or about $25 \%$ of the total land area of 16 Indonesian lands [3]. Generally, dry land in Indonesia has acid soil. The problem faced in acid soil soybean cultivation is the reduced production yield obtained as a result of less than optimal environment. These constraints can be overcome and controlled by liming the land, but this method is less economical and can cause soil pollution. A more effective way is to develop tolerant varieties on acid soils through soybean seeeding programs.

Among the widely available Podzolic land in Indonesia, land in Lampung, South Sumatra, Jambi and Riau are considered to have the best opportunity to be developed into soybean fields and to prepare new land clearing for ex-forest with Podzolic soil types (Ultisol). [4]. Since 2500 $\mathrm{BC}$, soybean is a plant native to Mainland China and has been cultivated by humans. In line with the growing development of trade between countries that occurred at the beginning of the 19th century, causing the soybean plants also spread to various trade destinations, namely Japan, Korea, Indonesia, India, Australia, and America. At first, soybean was known by several botanical names, namely Glycine soja and Soja max. But in 1948, it was agreed that the botanical name that could be accepted in scientific terms, namely Glycine max (L.) Merill. Soybean crop classification as follows:

$\begin{array}{ll}\text { Kingdom } & \text { : Plantae } \\ \text { Division } & \text { : Spermatophyta } \\ \text { Subdivisions } & : \text { Angiosperms } \\ \text { Class } & \text { : Dicotyledoneae } \\ \text { Order } & \text { : Rosales } \\ \text { Family } & \text { : Leguminoseae } \\ \text { Genus } & : \text { Glycine } \\ \text { Species } & : \text { Glycine max (L.) Meril }\end{array}$


Soybean plants generally grow upright, bush-shaped, and are seasonal plants. The morphology of soybean plants is supported by its main components, namely roots, leaves, stems, pods and seeds so that growth can be optimal [5].

Two pieces of soybean seeds wrapped in the seed coat, the embryo is located between the pieces of seeds. The color of the seed coats are various. There are yellow, black, green and brown. The shapes of soybean seeds are generally round, oval, some are round or slightly flat. Seed size varies, depending on the variety. In Indonesia the size of seeds varies from 6 grams - 30 grams [6]. The growth of soybean stems can be divided into two types, namely determinate and indeterminate. The difference in this stem growth systems is based on the presence of flowers on the shoots. The growth of determinate type stems is indicated by stems that do not grow again when planting begins to flower. While indeterminate type stem growth is characterized when the shoots of the plant stems can still grow leaves, even though the plants have begun to flower [7]. The requirements for growing soybean plants can adapt to various types of soil and prefer mild to moderate textures and well drained soils. This plant is sensitive to saline conditions [8].

The varieties play an important role in the development of soybean planting because to achieve high productivity is largely determined by the potential yield of superior varieties planted. Potential yield of seeds in the field is still influenced by interactions between varieties of genetic factors and the management of growing environmental conditions. In general, new superior varieties are expected to fulfill several criteria including increasing production, improving production stability, fulfilling quality standards, according to cropping patterns applied by farmers, and according to different consumer demands in each region.

Although previously reported that mixed local varieties are still widely planted [9], but now it seems that in most soybean planting areas, farmers have planted superior varieties including Wilis, Argomulyo, Anjasmoro, and Kaba. In general, farmers are more interested in soybean varieties with the following characters: (a) high yield, (b) early to moderate age (10 g/100 seeds), (d) yellow to brown seed coat, (e) plants are not easy fall, (f) resistant/tolerant of pests and diseases, and $(\mathrm{g})$ pods are not easily broken.

Superior Varieties for Acid Dry Land:

1. Tanggamus variety with a potential yield of 2.8 tons / ha, resistant to lodging, and not easily broken,

2. Later variety with a yield potential of 2.50 tons/ha, resistant to lodging, and not easily broken,

3. Ratai variety with a yield potential of 2.70 tons/ha, and are somewhat resistant to thickening,

4. Seulawah variety with a yield potential of 2.50 tons/ha and is fairly resistant to lodging, and 
5. Rajabasa variety with a yield potential of 3.90 tons/ha, resistant to lodging, and adaptive to acid dry land [10].

Soybean breeding is aimed at obtaining superior varieties with high yield potential characteristics, reaching 2 tons/ha, early maturity (75 - 90 days), resistant to leaf rusts (Phakopsora pachyrhyzi), acid tolerant soil, and adapt well to soils without intensive processing [9]. The purpose of soybean breeding includes developing varieties that can adapt well to infertile land, plant life is relatively long to mid-sized, resistant to major disease pests, has good agronomic properties, good appearance and quality of seeds, adapts well to conditions lack of water and responsive to a better or fertile environment [11].

Among the widely available Podzolic land in Indonesia, land in Lampung, South Sumatra, Jambi and Riau are considered to have the best opportunity to be developed into soybean fields. In the 1980s, the preparation of new land clearing of former forest with Podzolic (Ultisol) soil type in Muara Ilir, Jambi by expert assistance from GTZ Germany, proves that Podzolic land can be converted into fertile soybean fields whose productivity reaches 2 tons/ha or more [4]. The word Ultisol comes from the Latin Ultimus which means the last or most eroded soil and shows the effect of the last leaching [12]. Ultisol is soil that is in the temperate to tropical region has an argillic / candlestick horizon in fragments with thick clay layers.

Ultisol has obstacles in its utilization such as soil acidity, high Aldd saturation, cation exchange capacity and low base saturation and very low weathered mineral content. This is because the level of weathering and ultisol formation runs faster in humid climates with high temperatures and high rainfall. So that the soil undergoes a very intensive washing process (very sensitive to erosion) [13]. The Agricultural Research and Development Agency has produced various technological innovations that can increase soybean productivity, including superior varieties that have been partially developed by farmers. In line with the development of science and technology, the Indonesian Agency for Agricultural Research and Development has also produced and developed through an Integrated Crop Management (PTT) approach that was able to increase soybean productivity and production input efficiency.

\section{Materials and Method}

\subsection{Materials}

The material used in this study is ultisol soil and soybean seeds derived from Malang Balitkabi which consists of V1 (Anjarmoro Variety), V2 (Dena1 Variety), V3 (Deja 1 Variety), and V4 (Detap 1 Variety). The tools used in this study are hoes, machetes, raffia ropes, $\mathrm{pH}$ meters, plywood brand planks, buckets, watering can, meters, stationery,books for writing data and other laboratory equipment used for soil and plant analysis purposes. 


\subsection{Time and Location}

This study was conducted in Gulo Village, Darul Hasanah District, Southeast Aceh Regency, Aceh Province, at an altitude of 3200 above sea level (asl) from May to September 2019.

\subsection{Method}

The research was carried out in farms (ultisol soil land) by making 4 plots of plant plots with 4 replications. Then dolomite was given as much as $500 \mathrm{~kg} / \mathrm{ha}$, which was given ring placement in a row of plants, then given manure. Before planting, the soil is measured with a $\mathrm{pH}$ meter, then given $500 \mathrm{~kg}$ ha-1 of Dolomite. Dolomite plays a role to temporarily hold nutrients in rooting area, so Urea fertilizer and the given $\mathrm{KCl}$ is more efficient.

\subsection{Planting}

Planted 2 seeds of soybean/planting hole according to the variety used right on each treatment plot (planting using a tugal system with a depth of $3 \mathrm{~cm}$. each planting hole contains 2 seeds. $40 \times 10 \mathrm{~cm}$ spacing so that in one plot there are 63 planting holes)

\subsection{Maintenance}

The maintenance is done by watering the soybeans every day and in a roomy capacity and for cleaning the weeds by pulling weeds by hand. Then fertilized with a dose of $300 \mathrm{~kg} / \mathrm{ha}$ NPK, and $500 \mathrm{~kg}$ ha-1 manure.

\subsection{Harvesting}

Before harvesting, in vegetative period, height measurements were carried out on the sample plants starting from the base of the stem to the highest leaf tips carried out on plant samples aged 1 WAP, 2 WAP, 3 WAP, 4 WAP, 5 WAP until the end of the vegetative period 6 Weeks After Planting (WAP). Then soybean plants were given an attention when it starts flowering, and when it starts harvesting, at harvest time, sample plants were taken in each plot and then counted how many main stem segments, number of productive branches, total number of pods, number of pods contained, total empty pods, number of seeds of sample plants, weight of 100 seeds and number of seeds per pod.

\subsection{Research Observations}

The observations were done include:

1. The phase of plant growth, the observation of the vegetative phase was done by observing the growth of plant height aged 1 WAP, 2 WAP, 3 WAP, 4 WAP, 5 WAP and 6 WAP (Weeks after Planting).

2. Generative phase.

While observations on the generative phase include:

a. Flowering age (The Day After Planting/ DAP) 
b. Flowering age is carried out by observation in the fourth week to the eighth week (the day after planting/DAP).

c. Harvesting time (The Day After Planting/ DAP)

d. Harvesting is done when $\pm 80 \%$ of plants in each unit of experiment have shown ripe pods accompanied by yellowing and deciduous leaves.

e. Number of productive branches

f. The number of productive branches could be known by counting the number of branches that produce pods.

g. Number of productive segments

h. The number of productive segments could be observed by counting the number of books that produce pods.

i. Number of contained pods

j. Number of contained pods was known by counting all pods that produce seeds.

k. The number of empty pods

1. It was counted from pods that did not produce seeds.

m. Number of total pods

n. Total number of pods was calculated by summing contained pods with empty pods.

o. Number of seeds per pod

p. The number of seeds per pod was calculated by counting the number of seeds in one plant divided by the number of pods.

q. Weight of 100 seeds (grams)

r. Weight of 100 seeds was calculated by weighing 100 soy beans.

\subsection{Data Analysis}

Research data were analyzed using analysis of variance

$$
\mathrm{Y}_{\mathrm{ij}}=\mu+\mathrm{P}_{\mathrm{i}}+\mathrm{t}_{\mathrm{j}}+\varepsilon_{\mathrm{i} j}
$$

Explanation:

$\mathrm{Y}_{\mathrm{ij}}$ : Observations from the $\mathrm{i}$-th block with the $\mathrm{J}$ treatment

$\mu \quad$ : Middle value

Pi : The effect ofthe i block

$t_{j}$ : The influence of the i-th block that gets the J-treatment.

$\sum_{\mathrm{ij}} \quad$ : Effects of trial errors on i-block receiving J-treatment

The results of the research that show the real effect will be continued with the smallest Real Difference test (LSD) at the level of $0.5 \%$. 


\section{Results and Discussions}

\subsection{Generative Component}

In the description of soybean plants for flowering age and age of harvest/cooking of Anjasmoro soybean plants 35 days and 85 days of harvesting, Dena 1 varieties flowering 31 days and 71 days harvesting, Deja 1 flowering 35 days and 79 days harvesting and Detap 1 flowering 35 days and harvesting 79 days. Harvest age is determined by genetic factors and environmental conditions such as climate, elevation and growing season. In addition, the age of harvest is also determined by the interaction between the environment and varieties.

The difference in age of flowering and age of cooking is due to differences in altitude conditions. If soybean plants are planted in the lowlands (approximately $10 \mathrm{~m}$ above sea level) the plants will mature 4 days faster, the plants are longer and the number of pods is higher than soybeans that are cultivated at higher elevations [14]. In accordance with the planting carried out in this study precisely at an altitude of $3200 \mathrm{~m}$ above sea level (asl)

Table 1. Number of Productive Segments, Number of Productive Branches, Total Number of Pods, Number of Contained Pods, Number of Empty Pods.

\begin{tabular}{ccccccc}
\hline No & Varieties & $\begin{array}{c}\text { Number of } \\
\text { Productive } \\
\text { Segments }\end{array}$ & $\begin{array}{c}\text { Number of } \\
\text { Productive } \\
\text { Branches }\end{array}$ & $\begin{array}{c}\text { Total } \\
\text { Number } \\
\text { of Pods }\end{array}$ & $\begin{array}{c}\text { Number of } \\
\text { Contained } \\
\text { Pods }\end{array}$ & $\begin{array}{c}\text { Number } \\
\text { of Empty } \\
\text { Pods }\end{array}$ \\
\hline 1 & Anjasmoro & $11.11 \mathrm{a}$ & $3.60 \mathrm{~b}$ & $36.64 \mathrm{c}$ & $28.90 \mathrm{~b}$ & $7.85 \mathrm{~b}$ \\
2 & Dena 1 & $10.70 \mathrm{a}$ & $3.35 \mathrm{~b}$ & $25.73 \mathrm{~b}$ & $13.39 \mathrm{a}$ & $10.92 \mathrm{~b}$ \\
3 & Deja 1 & $13.89 \mathrm{c}$ & $4.20 \mathrm{c}$ & $54.93 \mathrm{~d}$ & $40.43 \mathrm{c}$ & $13.75 \mathrm{c}$ \\
4 & Detap 1 & $11.64 \mathrm{~b}$ & $1.42 \mathrm{a}$ & $17.70 \mathrm{a}$ & $12.73 \mathrm{a}$ & $4.35 \mathrm{a}$ \\
\hline BNT0,05 & & 0.58 & 0.64 & 8.01 & 9.45 & 3.48 \\
\hline
\end{tabular}

Note: the parallel rate followed by the same letter is not significantly different at the $0.05 \%$ level

All generative components showed significant differences between the number of productive segments, the number of productive branches, the total number of pods, the number of filled pods, and the total number of empty pods. The highest number of productive segments in Deja 1 variety was significantly different from Detap 1 variety and Detap 1 variety was significantly different from Anjasmoro varieties, and Anjasmoro varieties was not significantly different from Dena 1 varieties.

The highest number of productive branches per plant in Deja 1 variety was significantly different from Anjasmoro variety, and Anjasmoro variety was not significantly different from Dena 1 variety and significantly different from Detap Variety 1 . In this case the highest number of productive branches was in Deja I according to the research [7] which stated that the number of branches in soybeans depends on the variety, but generally the branches in soybeans number between 1-5 branches according to the characteristics that existed in Deja I and many factors affected the branching of soybean plants from their genotype, photoperiod and water temperature and minerals. The highest number of total pods in the Deja 1 variety, which was 
significantly different from the Anjasmoro variety and significantly different from the Dena 1 variety and Detap 1 variety.

The number of pods per plant in the shaded environment was reduced, include around 17 pods are reduced and this condition occured due to the shade-sensitive phase [15]. The highest number of seed pods was also found in Deja 1, which was significantly different in Anjasmoro, Dena 1 and Detap 1 variety. The lowest total empty pods were found in the Detap 1 variety, while the highest in Deja 1 was significantly different from the Dena and Anjasmoro variety.

Table 2. Number of Seeds of Sample Plants, Seed Weight of Sample Plants, Weight of 100 Seeds/Plant and Number of Seeds per Pod

\begin{tabular}{cccccc}
\hline No & Varieties & $\begin{array}{c}\text { Number of } \\
\text { Seeds of } \\
\text { Sample } \\
\text { Plants }\end{array}$ & $\begin{array}{c}\text { Seed Weight } \\
\text { of Sample } \\
\text { Plants }\end{array}$ & $\begin{array}{c}\text { Weight of } \\
\text { 100 Seeds/ } \\
\text { Plant }\end{array}$ & $\begin{array}{c}\text { Number } \\
\text { of Seeds } \\
\text { per Pod }\end{array}$ \\
\hline 1 & Anjasmoro & $45.12 \mathrm{a}$ & $8.01 \mathrm{a}$ & $17.31 \mathrm{a}$ & $1.40 \mathrm{a}$ \\
2 & Dena 1 & $27.98 \mathrm{a}$ & $5.96 \mathrm{a}$ & $16.13 \mathrm{a}$ & $1.11 \mathrm{a}$ \\
3 & Deja 1 & $76.20 \mathrm{~b}$ & $12.43 \mathrm{~b}$ & $16.56 \mathrm{a}$ & $1.49 \mathrm{a}$ \\
4 & Detap 1 & $27.64 \mathrm{a}$ & $4.72 \mathrm{a}$ & $18.50 \mathrm{a}$ & $1.51 \mathrm{a}$ \\
\hline BNT0,05 & & 18.71 & 4.13 & - & - \\
\hline
\end{tabular}

Note: the parallel rate followed by the same letter is not significantly different at the $0.05 \%$ level

The weight character of seeds per plant is an important character that can be used for direct selection criteria in order to get high yielding varieties. Seed weight per plant sample was highest in Deja 1 variety, 12.43 significantly different from Anjasmoro 8.01 variety and not significantly different in Dena 1 variety 5.96 and Detap 4.72. Weight of 100 seeds per pod and total number of seed per hole were found to be significantly different. In accordance with the description of each variety has a different response to the environment so that growth and results are also different

\section{Conclusions}

1. Each variety has a different response to the environment so that growth and yields are also different.

2. The Deja 1 variety has the highest yield for the number of seeds, and the weight of the seeds per plant compared to other varieties, even though the Detap 1 variety has a weight of 100 seeds and a higher total number of seeds per pod.

3. Deja 1 variety can be developed in Southeast Aceh with its soil and environmental conditions. 


\section{REFERENCES}

[1] E. Ginting, S. S. Antarlina, and S. Widowati, "Varietas Unggul Kedelai untuk Bahan Baku Industri Pangan," J. Litbang Pertan., vol. 28, no. 3, pp. 79-87, 2009.

[2] S. Hardjowigeno, "Klasifikasi Tanah dan Lahan. Dalam Muhidin, 2004. Uji Cepat Toleransi Tanaman Kedelai terhadap Cekaman Aluminium. Mimbar Akademik," J. Ilm. Univ. Haluoleo, Ed. Maret, vol. 26, pp. 18-24, 1985.

[3] H. Subagyo, N. Suharto, and A. B. Siswanto, Tanah pertanian di Indonesia. dalam pengembangan dan manajemen tanah-tanah di Indonesia. Bogor: Pusat Penelitian Tanah dan Agroklimat, 2004.

[4] G. J. Khol, "Pilot Project on Integrated Soya and Food Crops Development," Jakarta, 1983.

[5] T. Adisarwanto, Kedelai. Jakarta: Penebar Swadaya, 2005.

[6] H. S. Suprapto, Bertanam kedelai. Penebar Swadaya, 1985.

[7] T. Adisarwanto, Budidaya dengan Pemupukan yang Efektif dan Pengoptimalan Peran Bintil Akar Kedelai. Bogor: Penebar Swadaya, 2005.

[8] V. E. Rubatzky and M. Yamaguchi, Sayuran Dunia: Prinsip, Produksi dan Gizi. Bandung: Penerbit ITB Bandung, 1998.

[9] S. Sumarno and M. M. Adie, "Strategi pengembangan produksi menuju swasembada kedelai berkelanjutan," Iptek Tanam. Pangan, vol. 5, no. 1, 2015.

[10] F. Lisdiana, Budidaya kacang-kacangan. Jakarta: Penebar Swadaya, 2000.

[11] L. Gunawan et al., Varietas unggul dan strategi pemuliaan kedelai di Indonesia. Direktorat Teknologi Lingkungan. Badan Pengakajian dan Penerapan Teknologi. Pusat Penelitian dan Pengembangan Pertanian. Badan Penelitian dan Pengembangan Pertanian. Kementerian Pendidikan, Sains, Riset dan Teknologi Jerman, 2000.

[12] H. D. Foth, Dasar-dasar Ilmu Tanah Edisi Keenam. Jakarta: Erlangga, 1994.

[13] M. Munir, Tanah-Tanah Utama Indonesia: Karakteristik, Klasifikasi, dan Pemanfaatannya. Jakarta: Pustaka Jaya, 1996.

[14] M. M. Adie and A. Krisnawati, Biologi Tanaman Kedelai. Bogor: Pusat Penelitian dan Pengembangan Tanaman Pangan. Badan Penelitian dan Pengembangan Pertanian, 2007.

[15] C. Mathews, K. Van Holde, and K. Ahern, Biochemistry (3rd edn). (eds), vol. 4, no. 3. San Fransisco: Benjamin/Cummings, 2001. 